UDC 621.01

S. Koshel, PhD, Assoc. Prof., G. Koshel, PhD, Assoc. Prof.

Kyiv National University of Technologies and Design, 2 Nemirovich-Danchenko Str., 01011 Kyiv, Ukraine; e-mail: a_koshel@ukr.net

\title{
DEFINITION OF ACCELERATIONS OF POINTS OF A PLANE MECHANISM OF THE FOURTH CLASS BY GRAPH-ANALYTICAL METHOD
}

\begin{abstract}
С.О. Кошель, Г.В. Кошель. Визначення прискорення точок плоского механізму четвертого класу графо-аналітичним способом. Складні багатоланкові плоскі механізми все частіше застосовуються в технологічному обладнанні легкої промисловості. Удосконалення існуючого технологічного устаткування легкої промисловості та проектування нових машин, пов'язано 3 ефективністю існуючих методів аналізу структурних груп ланок плоских механізмів, з яких останні складені. Методи дослідження діад $\epsilon$ найбільш розробленими сьогодні. Досить відомими $є$ методи аналізу структурної групи, до якої входять чотири ланки. Вони утворюють групи 3-го класу, на базі яких можна структурно синтезувати механізми відповідного класу. Структурні групи 4-го класу, з одного боку, вже використовуються або мають певні перспективи застосування в машинах технологічного обладнання легкої промисловості, 3 іншого - доцільність (ефективність) іх використання теоретично не обгрунтована, оскільки немає універсального відомого методу їх кінематичного та динамічного досліджень. Недосконалість методів аналізу таких структурних груп $є$ фактором стримування їх використання в технологічному обладнанні, тому можна стверджувати, що роботи з кінематичного аналізу багатоланкових механізмів четвертого та більше класів є актуальними. Метою роботи є розробка послідовностей дій для кінематичного дослідження прискорень точок ланок складного плоского механізму четвертого класу графоаналітичним способом, що базується на положеннях курсу теоретична механіка про миттєвий центр прискорень ланок механізму, що мають плоскопаралельний рух. Визначено вектори лінійних прискорень точок ланок групи четвертого класу другого порядку складного плоского механізму графоаналітичним методом, в якому умовно змінено початковий механізм, що призвело до зменшення класу механізму та дозволило виконати його дослідження.

Ключові слова: механізм, кінематичне дослідження, вектор швидкості, план швидкостей

S. Koshel, G. Koshel. Determination of accelerations of points of a plane mechanism of the fourth class by graph-analytical method. The use of complex plane mechanisms in processing equipment of consumer industry is increasing. Improvement of existing processing equipment of consumer industry and design of new machines is connected with efficiency of existing analysis methods applied for structural link groups of plane mechanisms, of which the last are composed. The methods of research of dyads are the most effective today. Well known are the methods of analysis of structural groups consisting of four links. They form the 3rd class groups, on the basis of which the mechanisms of the relevant class can be structurally synthesized. On the one hand the fourth class structural groups are already being used or have significant prospects of application in processing equipment of consumer industry, on the other - the appropriateness (effectiveness) of their use is not theoretically justified because there is no known method for their kinematic and dynamic researches. Imperfection of analysis methods of such structural groups is a limiting factor of their use in processing equipment. The absence of a general method of kinematic research of these mechanisms allows us to accentuate the relevance of work on kinematic analysis of multilink mechanisms. Purpose of the work is to develop sequence of actions for kinematic research of accelerations of link points of a complex plane mechanism using the grapho-analytical method based on the provisions of the "Theoretical Mechanics" course on instantaneous acceleration center of links of the mechanism, which have plane-parallel motion. The acceleration vectors of link points of the second order fourth class group of complex plane mechanism are analyzed using grapho-analytical method, which provisionally modified initial mechanism has led to a class reduction of mechanism and allowed to conduct its research.

Keywords: mechanism, kinematic research, the velocity vector, velocity vector diagram
\end{abstract}

Introduction. Design of new consumer industry machines and improvement of existing technological equipment depends on perfection of methods of structural, kinematic and dynamic research of structural groups of links of mechanisms. The methods of studying two-rail structural groups are the most developed, known are methods of analysis of plane groups of links, that form the third order third class groups or some fourth class ones, on the basis of which it is possible to structurally synthesize the mechanisms of corresponding classes.

Plane structural groups of higher classes on the one hand are already being used or have significant prospects of application in mechanisms of consumer industry technological equipment; on the other hand there are no unified methods of kinematic and dynamic research, which can be explained by the diversity of types of structural groups and the complexity of research in each particular case. 
Analysis of basic research and publications. Issues of study of complex plane mechanisms are given attention in a number of publications of recent years: the problems of synthesis are considered and solved [1], kinematic and dynamic research of higher class mechanisms [2] is carried out, for example, the kinematic research of the mechanism of the sixth class [3, 4], in particular the mechanisms of consumer industry equipment $[5,6]$.

The insufficient development of methods for analyzing higher class structural groups is a constraining factor for their usage in technological equipment, in particular, in consumer industry machines, therefore those works remain relevant that deal with problems of the kinematic research of complex plane mechanisms using any other possible methods of analysis.

Purpose of the study. The purpose of the work is to develop sequence of actions for kinematic research of velocities of points that coincide with the geometric centers of kinematic pairs of the second order fourth class structural group with a movable closed loop formed by three connecting rods, one of which has the form of a complex link, and one rocker arm, connecting three elements of kinematic pairs, based on provisions of the course of the theory of mechanisms and machines on the property of higher classes mechanisms to change the class depending on the conditionally selected other possible initial mechanism, that comes from the driven structural groups of mechanism links, and provisions of theoretical mechanics course of instantaneous acceleration center (I.A.C.).

Presentation of the main material. Let us consider complex plane articulation linkage of the fourth class (Fig. 1), consisting of the driving link 1, which is connected to a stand-pipe 0 and other driven links $2 \ldots 5$, among which links $2 \ldots 4$ are connecting rods, $5-$ a rocker arm. The first class mechanism (links 0,1 ) together with the fourth class second order structural group, which consists of a set of four movable links $2 \ldots .5(n=4)$ along with six kinematic pairs of the fifth class $A, B, C, D, E, K$, $\left(p_{5}=6\right)$ form a fourth class mechanism with a degree of freeness equal to 1 , that is, they form a mechanism with one driving crank. The formula of the complex mechanism structure that is being studied has the following form: 1class (links 0,1) $\rightarrow$ 4class 2order (links 2...5) .

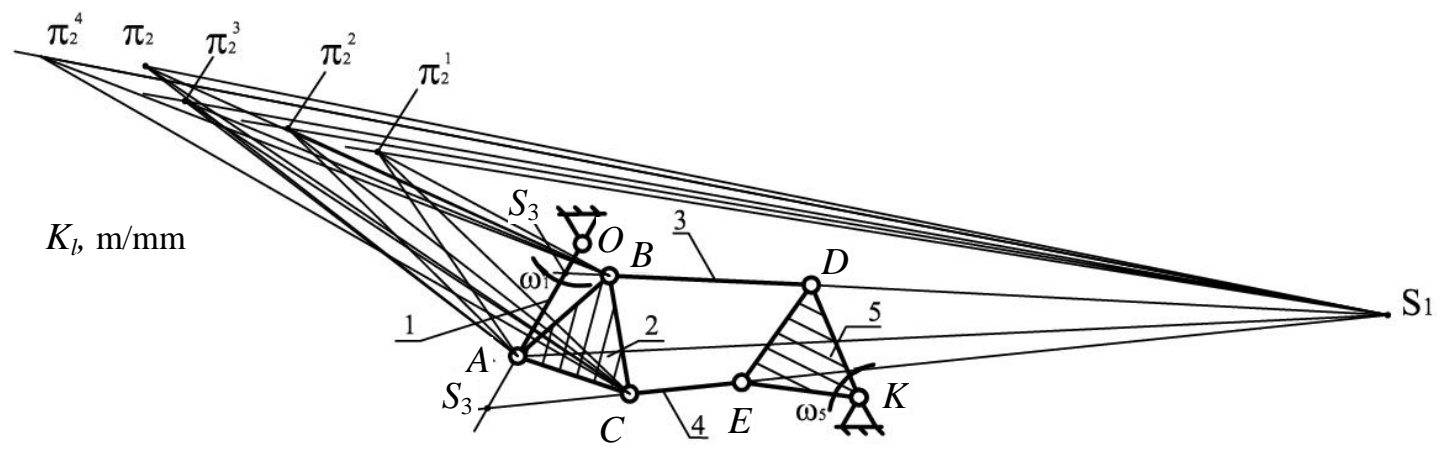

Fig. 1. Kinematic scheme of the fourth class mechanism

The structural feature of the mechanism is the presence of a shape-variable closed loop $B, C, D, E$ formed by three connecting rods $A B C, B D, C E$ (two of which $B D$ and $C E$ are located opposite to each other and have the form of simple links, while the last one has the form of a complex link) and one rocker arm $E D K$.

It is not possible to perform a kinematic analysis of the mechanism in the sequence and manner in which the complex third-class mechanisms are usually studied using the grapho-analytical method. It is due to the fact that the connecting rod 2, which is directly attached to the crank 1 by the kinematic pair $A$, and from the other side pairs $B, C$ are connected to the connecting rods 3 , 4, kinematic parameters of points and trajectories of which are unknown.

The input parameters for kinematic research of the mechanism are the angular velocity of the crank $1\left(\omega_{1}=\right.$ const, $\left.\mathrm{s}^{-1}\right)$ and the length scale $\left(K_{l}, \mathrm{~m} / \mathrm{mm}\right)$ of the kinematic scheme of the mechanism.

The grapho-analytical method of kinematic research is used. The problem is solved using general provisions of the kinematic analysis of mechanisms of the "Theory of Mechanisms and Machines" 
course and the provisions of the "Theoretical Mechanics" course, in relation to the study of the planeparallel motion of a solid body.

We take into account the structural property of the higher-order mechanisms to change the class in case of conditional change of the initial mechanism to another possible first-class mechanism [7].

If we choose a set of links 0,5 for the initial mechanism - the mechanism becomes the third class mechanism, which structure can be described the following way: 1class (links 0,5) $\rightarrow$ 3class 3order (links 1...4).

Kinematical research begins when the angular acceleration $\left(\varepsilon_{5}, \mathrm{~s}^{-2}\right)$ of the rocker arm 5 is arbitrarily assigned in magnitude and direction similar to a link, which, according to the formula of the mechanism structure, is another arbitrarily possible driving link of the mechanism: on the accelerator diagram (Fig. 2) let us mark vectors $\overrightarrow{\pi e}, \overrightarrow{\pi d}$ on the basis of pre-calculated normal accelerations of the points $D, E\left(a_{D ; K}^{n}=\omega_{5}^{2} \cdot l_{D K}, a_{E ; K}^{n}=\omega_{5}^{2} \cdot l_{E K}\right)$, which, respectively, are directed parallel to the lines $D K$ and $E K$, tangential - perpendicular to them.

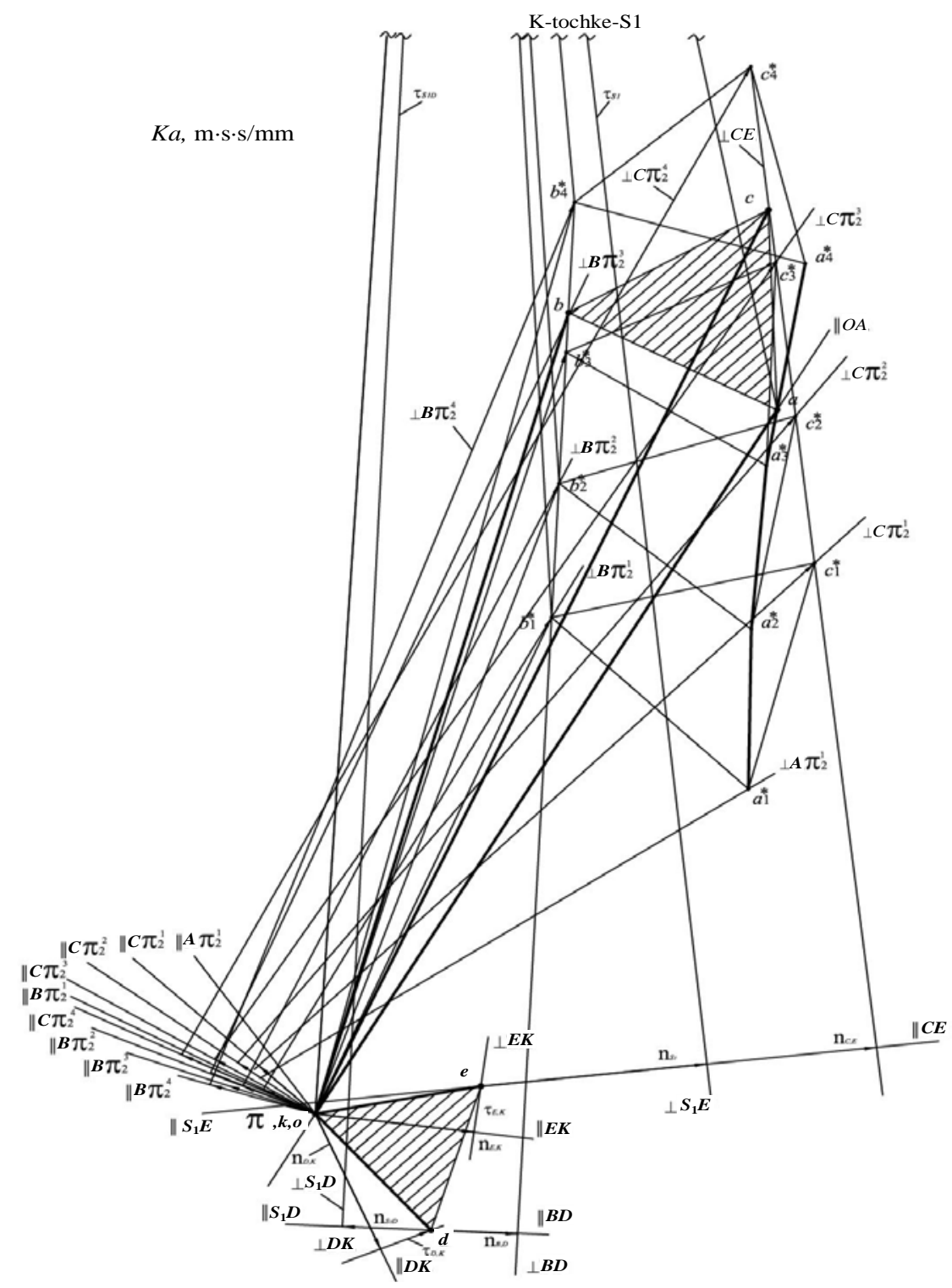

Fig. 2. Accelerator diagram of the fourth class mechanism 
Let us construct a system of vector equations for determining acceleration of the singular Assur point $S_{1}$ of link 2:

$$
\left\{\begin{array}{l}
\vec{a}_{S 1}=\vec{a}_{B}+\vec{a}_{S 1 ; B}^{n}+\vec{a}_{S 1 ; B}^{\tau}=\vec{a}_{D}+\vec{a}_{B ; D}^{n}+\vec{a}_{B ; D}^{\tau}+\vec{a}_{S 1 ; B}^{n}+\vec{a}_{S 1 ; B}^{\tau} ; \\
\vec{a}_{S 1}=\vec{a}_{C}+\vec{a}_{S 1 ; C}^{n}+\vec{a}_{S 1 ; C}^{\tau}=\vec{a}_{E}+\vec{a}_{C ; E}^{n}+\vec{a}_{C ; E}^{\tau}+\vec{a}_{S 1 ; C}^{n}+\vec{a}_{S 1 ; C}^{\tau} \cdot
\end{array}\right\}
$$

Normal acceleration from the equation (1) in magnitude is determined from the following equations:

$$
\left\{\begin{array}{l}
\vec{a}_{S 1 ; B}^{n}=\omega_{2}^{2} \cdot l_{S 1 ; B} ; \\
\vec{a}_{B ; D}^{n}=\omega_{3}^{2} \cdot l_{B ; D} ;
\end{array}\right\} \text { and }\left\{\begin{array}{l}
\vec{a}_{S 1 ; C}^{n}=\omega_{2}^{2} \cdot l_{S 1 ; C} ; \\
\vec{a}_{C ; E}^{n}=\omega_{4}^{2} \cdot l_{C ; E},
\end{array}\right\}
$$

and in direction - from the kinematic scheme. It should be noted that normal acceleration in each equation of the system (1) has the same direction, but can be pointed in opposite directions, so let us act as follows: if the directions of the vectors are different, then the resulting vector is pointed towards the larger acceleration, that is, we mark their algebraic difference with the direction of the larger acceleration.

After that we build vector equations that allow us to construct a line of possible positions of the points " $b$ " and " $c$ " on the accelerator diagram, which are the ends, respectively, of the acceleration vectors of points $B$ and $C: \vec{a}_{B}=\vec{a}_{D}+\vec{a}_{B ; D}^{n}+\vec{a}_{B ; D}^{\tau}, \vec{a}_{C}=\vec{a}_{E}+\vec{a}_{C ; E}^{n}+\vec{a}_{C ; E}^{\tau}$, and construct them (the lines which are marked $\perp B D$ and $\perp C E$ according to the equations).

On the line of possible positions of the point " $b$ " we arbitrarily assign a possible position (point $\left.b_{1}^{*}\right)$, that is, we actually randomly choose the magnitude of angular acceleration $\left(\varepsilon_{3}, \mathrm{~s}^{-2}\right)$ of the connecting rod 3 . Then, according to the similarity theorem for the three points $\left(S 1, B, \pi_{2}^{i}\right)$ belonging to one link, one can make the following similarity: $\Delta S_{1} B \pi_{2}^{i} \cong \Delta s_{1} b_{1}^{*} \pi$, from which we determine the position of the point $\pi_{2}^{i}-$ I.A.C. of connecting rod 2 on the position plan of the mechanism.

According to the determined position of the point $\pi_{2}^{i}$ we build a vector equation allowing to check the position of the point $b_{1}^{*}$ on the accelerator diagram: $\vec{a}_{B}=\vec{a}_{B ; \pi_{2}^{1}}^{n}+\vec{a}_{B ; \pi_{2}^{1}}^{\tau}$ (the normal acceleration is calculated as follows: $a_{B ; \pi_{2}^{1}}^{n}=\omega_{2}^{2} \cdot l_{B ; \pi_{2}^{1}}$ ) and an equation allowing to find the corresponding position of the point $c_{1}^{*}$ on the line of its possible positions: $\vec{a}_{C}=\vec{a}_{C ; \pi_{2}^{1}}^{n}+\vec{a}_{C ; \pi_{2}^{1}}^{\tau}$, where the normal acceleration is calculated using the following equation: $a_{C ; \pi_{2}^{1}}^{n}=\omega_{2}^{2} \cdot l_{C ; \pi_{2}^{1}}$.

According to the similarity theorem for three points $(A, B, C)$ belonging to one link, we form a similarity: $\triangle A B C \cong \triangle a_{1}^{*} b_{1}^{*} c_{1}^{*}$, from which we determine the position of the point $a_{1}^{*}$ on the accelerator diagram - its position does not correspond to the actual position because it is not on the line of its possible positions (when the crank has constant angular velocity, a line passing through the pole of the accelerator diagram in direction parallel to the geometric axis of the crank 1 , that is, $\| A O$, will be the line of possible positions of the point " $a$ ").

The further solution is to arbitrarily assign other possible positions of the point " $b$ " (points " $b_{2}^{*}$ ",

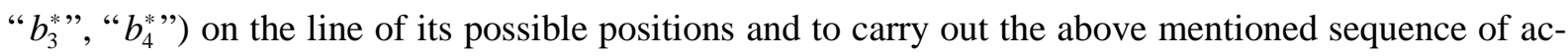
tions, which will facilitate obtaining an assembly of points " $a_{2}^{*}$ ”, “ $a_{3}^{*}$ ”, " $a_{4}^{*}$ ” of the line of false positions of points " $a$ " on the accelerator diagram, that has the form of a plane curve of the second order $\left(a_{1}^{*} a_{4}^{*}\right.$ ). The actual position of the point " $a_{1}^{*}$ " (point " $a$ " of the accelerator diagram) is determined at the intersection of the lines of its actual and false positions.

Using actual position of the point " $a$ " according to the similarity theorem ( $\left.\Delta S_{1} A \pi_{2} \cong \Delta s_{1} a \pi\right)$ we clarify the actual position of the I.A.C. point of the connecting rod $2\left(\pi_{2}\right)$ on the kinematic scheme of the mechanism by which we determine the actual angular acceleration $\left(\varepsilon_{2}, s^{-2}\right)$ of the link 2 and the actual linear acceleration of the points $B$ and $C: \vec{a}_{B}=\vec{a}_{B ; \pi_{2}}^{n}+\vec{a}_{B ; \pi_{2}}^{\tau} ; \vec{a}_{C}=\vec{a}_{C ; \pi_{2}}^{n}+\vec{a}_{C ; \pi_{2}}^{\tau}$. We make up the 
systems of vector equations allowing to construct the vectors of linear accelerations of points $D$ and $E$ on the accelerator diagram:

$$
\left\{\begin{array}{l}
\vec{a}_{D}=\vec{a}_{B}+\vec{a}_{D ; B}^{n}+\vec{a}_{D ; B}^{\tau} ; \\
\vec{a}_{D}=\vec{a}_{K}+\vec{a}_{D ; K}^{n}+\vec{a}_{D ; K}^{\tau} ;
\end{array}\right\}\left\{\begin{array}{l}
\vec{a}_{E}=\vec{a}_{C}+\vec{a}_{E ; C}^{n}+\vec{a}_{E ; C}^{\tau} ; \\
\vec{a}_{E}=\vec{a}_{K}+\vec{a}_{E ; K}^{n}+\vec{a}_{E ; K}^{\tau} \cdot
\end{array}\right\}
$$

The acquired accelerator diagram is perceived as a graphical construction where the vectors of linear accelerations of the points of the fourth class mechanism are constructed from a pole at an indefinite scale, which, taking into account the given size of the links and the angular velocity of the actual driving link (crank 1), is not difficult to calculate.

Conclusions. The sequence of actions was developed and the kinematic research of velocities of points coinciding with the geometric centers of the kinematic pairs of the second order fourth class structural group with a movable closed loop formed by three connecting rods, one of which has the form of a complex link, and one rocker arm, connecting three elements of kinematic pairs, based on provisions of the course of the theory of mechanisms and machines on the property of higher classes mechanisms to change the class depending on the conditionally selected other possible initial mechanism, that comes from the driven structural groups of mechanism links, and provisions of theoretical mechanics course of instantaneous acceleration center.

The proposed sequence of kinematic analysis can be recommended for similar studies of complex plane mechanisms of the fourth and higher classes.

\section{Література}

1. Кикин А.Б., Пейсах Э.Е. Аналитико-оптимизационный синтез шестизвенного механизма с выстоем. Известия высших учебных заведений. Технология текстильной промышленности. 2008. № 5. С. 79-83.

2. Дворников Л.Т., Стариков С.П. Исследование кинематики и кинетостатики плоской шарнирной шестизвенной группы Ассура с четырехугольным замкнутым изменяемым контуром. Известия высших учебных заведений. Машиностроение. 2008. №4. С. 3-10.

3. Чашников Д.О., Гаряшин В.В. Кинематическое исследование плоского восьмизвенного механизма шестого класса с поступательной парой. Успехи современного естествознания. 2011. № 7. С. 231-232.

4. Чашников Д.О., Гаряшин В.В. Кинематическое исследование плоского восьмизвенного механизма шестого класса с поступательной парой аналитическим методом. Успехи современного естествознания. 2012. №6. С. 158-159.

5. Гебель Е.С., Солонин Е.В. Моделирование кинематики механизма игл основовязальной машины. Теоретические знания в практические дела: сборник материалов Х междунар. научно-практ. конф.: в 2 ч. Омск.: 2009. Ч. 2. С. 211-215.

6. Кикин А.Б. Синтез рычажных механизмов для привода нитераскладчика мотальной машины. Известия выстих учебных заведений. Технология текстильной промышленности. 2005. № 1. C. $115-119$.

7. Кошель С.О., Кошель Г.В. Структурний аналіз складних плоских механізмів четвертого класу. Вісник Хмельницького національного університету. Технічні науки. 2015. №1. С. 72-79

\section{References}

1.Kikin, A.B. \& Pejsah, Je.E. (2008). Analytical and optimal synthesis of six-membered mechanism with dwell. Proceedings of Higher Education Institutions: Technology textile industr, 5, 79-83.

2.Dvornikov, L.T. \& Starikov, S.P. (2008). The study of kinematics and Kinetostatics flat hinged sixmembered group Assur quadrangular closed loop variable. Proceedings of Higher Education Institutions: Engineering, 4, 3-10.

3.Chashnikov, D.O. \& Garyashin, V.V. (2011). Kinematic study of planar six sixth grade mechanism with sliding pair. Uspehi sovremennogo estestvoznaniya, 7, 231-232.

4.Chashnikov, D.O. \& Garyashin, V.V. (2012). Kinematic study of planar six sixth grade mechanism with sliding pair analytical method. Advances in Current Natural Sciences, 6, 158-159. 
5.Gebel, E.S. \& Solonin, E.V. (2009). Kinematics modeling of needle mechanism of warp-knitting machine. In Proceedings of 10th International Scientific and Practical Conference "Theoretical Knowledge - into Practice”, Vol. 2, pp. 211-215, Omsk : MSUTM named after K.G. Razumovsky.

6.Kikin, A.B. (2005). Linkages synthesis to drive of the thread spreading for a winding machine. Proceedings of Higher Education Institutions:Technology textile industry, 1, 115-119.

7.Koshel, S.O. \& Koshel, G.V. (2015). Structurally analiz folding flat mehanizmiv fourth class. Herald of Khmelnytskyi national university. Technical sciences, 1, 72-79.

Кошель Сергій Олександрович; Koshel Sergey, ORCID: https://orcid.org/0000-0001-7481-0186

Кошель Ганна Володимирівна; Koshel Ganna, ORCID: https://orcid.org/0000-0003-1862-1553

Received May 04, 2018

Accepted June 21, 2018 